A new way to assess the management of biodiversity in companies

\title{
The Ecosystem Services Benchmark
}

\begin{abstract}
The impacts and dependences of companies on natural resources is a key factor for their future performance. The new Ecosystem Services Benchmark identifies risks and performances of companies and provides a strategic framework on the issue, often overlooked in established management systems. By Margot Hill, Ivo Mulder, Annelisa Grigg, Zoe Cullen and Jack Foxall
\end{abstract}

O ver 60 percent of the ecosystem services on which we rely, are being degraded and overexploited from the agricultural sector, forestry, fisheries, and many others (MEA 2005). Unpredictable weather, competition for land between biofuels and traditional crops and declines in soil fertility are severely affecting our agricultural system. The degradation of ecosystem services such as freshwater provision, climate regulation and soil fertility clearly has implications for the longterm viability of the businesses dependent on them, in particular those with agricultural supply chains.

\section{The business case for natural value}

Increasingly this is translating to business risk and opportunity. Ecosystem services are the benefits that people obtain from ecosystems, such as freshwater, timber, climate regulation, protection from natural hazards, erosion control and recreation. A company depends on an ecosystem service if that service functions as an input or if it enables, enhances or influences environmental conditions required for successful corporate performance. A company impacts an ecosystem service if the company affects the quantity or quality of the service (Hanson et al. 2008).

There are a number of risks and opportunities associated with ecosystem services for financial institutions, namely, operational risk, regulatory risk, reputa- tional risk and the potential to gain a competitive advantage. Despite these emerging risks and opportunities, there are few tools available to enable investors to understand the extent, to which companies are dependent on, or impact on, biodiversity and ecosystem services. As a result, company exposure to the risks above is unclear.

The Natural Value Initiative, an initiative led by Fauna \& Flora International in collaboration with the United Nations Environment Programme Finance Initiative and Brazilian business school Fundação Getulio Vargas, aims to address this gap by creating a toolkit to enable institutional investors to better understand the impacts and dependency of their investments on biodiversity and ecosystem services (Grigg et al. 2009b)..

The Ecosystem Services Benchmark (ESB) and its pilot study with six investors and a selection of 31 companies within their portfolios is the result. It can be regarded as the first phase, part of a longer process to work with companies and investors to strengthen the recognition of material value of biodiversity and ecosystem services (BES) throughout the corporate and investment communities.

\section{Biodiversity benchmarking and financial institutions}

A benchmark can measure the quality of a company's policies, products, programmes or strategies and compares them with standard measurements, or si- milar measurements of the best-in-class companies. It aims to determine what and where improvements are called for, understand how other companies achieve their high performance levels and use this information to improve the company's performance.

Benchmarking provides an objective and consistent basis for examining comparative risk exposure and management of companies. The approach combines research into key issues using a structured analysis of company performance and engagement with investee companies (UNEP FI 2008). It provides a useful reference point for investors and companies to identify areas of strength and weakness. Benchmarks are most valuable where the issue is emerging and is overlooked by more holistic analyses of sustainability performance.

Corporate management of biodiversity and ecosystem services falls into this category. In such circumstances, benchmarks can provide a logical and strategic framework in which a company can start to evaluate the risks and opportunities associated with the issue.

\section{The Ecosystem Services Benchmark}

The ESB has been developed to enable institutional investors to better understand the risks and opportunities associated with their investment's management of their impacts and dependence on biodiversity and ecosystems services (Grigg et al. 2009a). The ESB focuses on these impacts and dependences associated with the production and harvesting of raw materials in companies with agricultural supply chains, including agricultural commodities, livestock and fish.

Most traditional measures of performance consider impacts only or just one element of environmental performance. The ESB has been designed specifically for evaluation of the food, beverage and tobacco sectors, but has broader applicability to any supply chain company with an agricultural or natural resources footprint. It evaluates companies on competitive advantage, governance, policy and 
strategy, management and implementation as well as reporting

\section{Results}

The key outputs of the first phase of this initiative comprised of a briefing document, apart from the ESB, for the food, beverage and tobacco sectors. As one would expect, the sectors that perform best within the ESB are those facing immediate pressures, such as consumer interest, campaigns from non-governmental organisations, investor expectations, or those where the materiality of ecosystem service dependence is very clear and already affecting the bottom line.

There is considerable activity across all sectors of relevance to BES. However, with the exception of the beverage sector, all sectors showed an average score that was at least 50 percent lower than the ideal. One of the companies analysed, Unilever, fell within the realm of best practice, albeit on the lower end of the scale. Marks \& Spencer came a close second. Both companies were distinguished by their well-documented, strategic and riskfocused approach that provided the ESB assessors with comfort that they had understood and were beginning to manage the issue.

\section{Conclusions and challenges}

Activity is required in a number of areas before a comprehensive and credible picture of risk and opportunity assessment and management can be demonstrated.

- Corporate risk assessment processes frequently did not adequately address biodiversity and ecosystem services. Despite a clear reliance of the companies evaluated on an agricultural supply chain dependent on healthy biodiversity and access to ecosystem services, only 48 percent of the companies had a well-communicated risk and opportunity assessment in place.

- Disclosures on BES were often inadequate for evaluating corporate performance. Less than half of the companies achieved level 3 or more (half marks) on the ESB's evaluation of the quality of their reporting on BES.

- Companies often lacked clear policy and strategy frameworks to drive action. Although 58 percent of the companies evaluated disclosed a statement of management approach on single commodities, only 16 percent of the companies had a clear BES policy and strategy framework.

- Supplier performance standards are in place which incorporate BES, but these are often limited in scope or voluntary in nature. Whilst 45 percent of the companies evaluated had standards or detailed guidelines for sustainable agriculture or guidelines for sustainable sourcing that encompassed BES, only three of these covered the majority of the companies' raw materials supply.

- Activity to build shareholder value and ensure continued raw material supply is widespread, but it may not be proportional to corporate impact or risk. It was encouraging that 65 percent of companies had some form of pilot programmes in place or were engaging with initiatives aimed at overcoming barriers to sustainable supply such as the Roundtable on Sustainable Palm Oil.

- Management tools that encompass BES issues exist but often only address a small part of the company's supply chain. 55 percent of the companies had developed tools relevant to the management of BES.

What we can learn from this initial analysis is that a number of companies in the agribusiness sectors that were benchmarked, have started to address BES issues in their business operations. These early activities will position these companies and those investors with an interest in them well to respond efficiently and rapidly to the challenges that will inevitably be posed by this increasingly resourceconstrained world.

Placing the results in a bigger context, though, it becomes apparent that there is a long road ahead for many companies to properly address BES issues across their company's value chain.

\section{References}

Grigg, A. / Cullen, Z. / Foxall, J. / Crosbie, L. / Jamison, L. / Brito R.: The Ecosystem Services Benchmark. A guidance document. Geneva 2009a.

Grigg, A. / Cullen, Z. / Foxall, J. / Strumpf, R.: Linking shareholder and natural value. Managing biodiversity and ecosystem services risk in companies with an agricultural supply chain. Geneva 2009b.

Hanson, C. / Ranganathan, J. / Iceland, C. / Finisdore, J.: The Corporate Ecosystem Services Review. Washington D.C. 2008. MEA (Millennium Ecosystem Assessment): Ecosystems and Human Well-being: Synthesis. Washington DC 2005.

UNEP Finance Initiative: Biodiversity and Ecosystem Services. Bloom or Bust? Geneva 2008.

I AUTHORS + CONTACT

Margot Hill and lvo Mulder work at the United Nations Environment Programme Finance Initiative (UNEP FI). UNEP FI is a partnership between UNEP and the global financial sector, including over 190 financial institutions. Margot Hill, UNEP FI, 15 chemin des Anémones, Geneva, Switzerland. Email: margot.hill@unep.org, Internet: http://www.unepfi.org

Annelisa Grigg, Zoe Cullen and Jack Foxall work at non-governmental organizations and financial institutions and are partners to UNEP FI. 


\section{Lizenzhinweis}

Die Beiträge in ÖkologischesWirtschaften werden unter der Creative-Commons-Lizenz "CC 4.0 Attribution Non-Commercial No Derivatives" veröffentlicht. Im Rahmen dieser Lizenz muss der Autor/Urheber stets genannt werden, das Werk darf nicht bearbeitet, abgewandelt oder in anderer Weise verändert und außerdem nicht kommerziell genutzt werden. Die digitale Version des Artikels bleibt für zwei Jahre Abonnent/innen vorbehalten und ist danach im Open Access verfügbar. 